\title{
Temperature Control System for Liquid-Fed Ceramic Melters
}

\author{
J. H. Westsik, Jr.
}

October 1986

Prepared for the U.S. Department of Energy under Contract DE-AC06-76RLO 1830

Pacific Northwest Laboratory Operated for the U.S. Department of Energy by Battelle Memorial Institute 


\title{
DISCLAIMER
}

This report was prepared as an account of work sponsored by an agency of the United States Government. Neither the United States Government nor any agency thereof, nor Battelle Memorial Institute, nor any of their employees, makes any warranty, expressed or implied, or assumes any legal liability or responsibility for the accuracy, completeness, or usefulness of any information, apparatus, product, or process disclosed, or represents that its use would not infringe privately owned rights. Reference herein to any specific commercial product, process, or service by trade name, trademark, manufacturer, or otherwise, does not necessarily constitute or imply its endorsement, recommendation, or favoring by the United States Government of any agency thereof, or Battelle Memorial Institute. The views and opinions of authors expressed herein do not necessarly state or reflect those of the United States Government or any agency thereof, or Battelle Memorial Institute.

\author{
PACIFIC NORTHWEST LABORATORY \\ operated by \\ BATTELLE \\ for the \\ UNITED STATES DEPARTMENT OF ENERGY \\ under Contract DE-AC06-76RLO 1830
}

\begin{tabular}{|c|c|}
\hline \multicolumn{2}{|c|}{ Printed in the United States of America } \\
\hline \multicolumn{2}{|c|}{ Available from } \\
\hline \multirow{4}{*}{\multicolumn{2}{|c|}{$\begin{array}{c}\text { National Technical Information Service } \\
\text { United States Department of Commerce } \\
5285 \text { Port Royal Road } \\
\text { Springfield, Virginia } 22161\end{array}$}} \\
\hline & \\
\hline & \\
\hline & \\
\hline \multirow{2}{*}{\multicolumn{2}{|c|}{$\begin{array}{l}\text { NTIS Price Codes } \\
\text { Microfiche A01 }\end{array}$}} \\
\hline & \\
\hline \multicolumn{2}{|c|}{ Printed Copy } \\
\hline & Price \\
\hline Pages & Codes \\
\hline $001-025$ & $\mathrm{~A} 02$ \\
\hline $026-050$ & $\mathrm{~A} 03$ \\
\hline $051-075$ & $\mathrm{~A} 04$ \\
\hline $076-100$ & A05 \\
\hline $101-125$ & A06 \\
\hline $126-150$ & A07 \\
\hline $151-175$ & $A 0 B$ \\
\hline $176-200$ & $\mathrm{~A} 09$ \\
\hline $201-225$ & A010 \\
\hline $226-250$ & A011 \\
\hline $251-275$ & A012 \\
\hline $276-300$ & $A 013$ \\
\hline
\end{tabular}


TEMPERATURE CONTROL SYSTEM FOR LIQUID-FED CERAMIC MELTERS

J. H. Westsik, Jr.

October 1986

Prepared for the U.S. Department of Energy under Contract DE-AC06-76RLO 1830

Pacific Northwest Laboratory

Richland, Washington 99352 


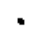

,

s

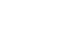

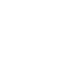


A temperature-feedback system has been developed for controlling electrical power to liquid-fed ceramic melters (LFCM). Software, written for a microcomputer-based data acquisition and process monitoring system, compares glass temperatures with a temperature setpoint and adjusts the electrical power accordingly. Included in the control algorithm are steps to reject failed thermocouples, spatialiy average the glass temperatures, smooth the averaged temperatures over time using a digital filter, and detect foaming in the glass. The temperature control system has proved effective during all phases of melter operation including startup, steady operation, loss of feed, and shutdown. This system replaces current, power, and resistance feedback control systems used previously in controlling the LFCM process. 

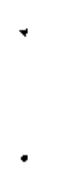


\section{ACKNOWLEDGMENTS}

G. A. Anderson and K. L. Schuchardt wrote the computer program for the temperature control algorithm. L. J. Ethridge conducted the tuning tests to

determine the controller parameters. S. K. Ennor edited the manuscript. Their contributions are greatiy appreciated. 


\section{CONTENTS}

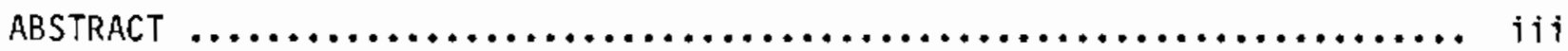

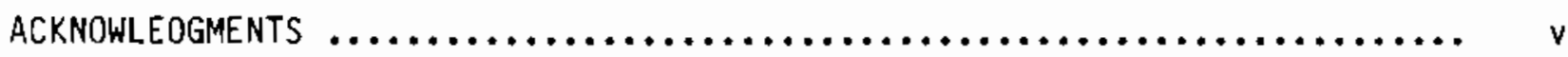

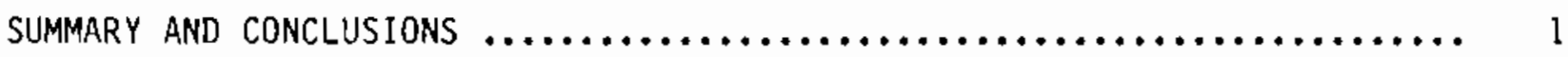

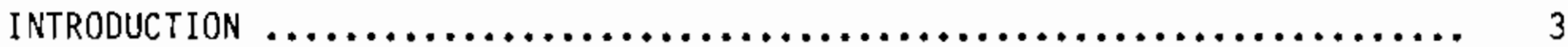

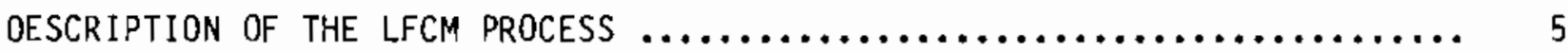

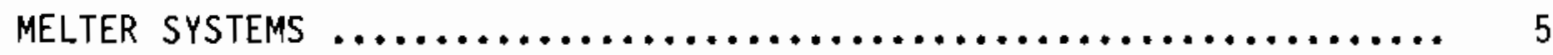

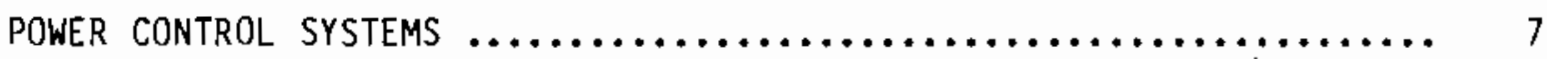

TEMPERATURE CONTROL SYSTEM $\ldots \ldots \ldots \ldots \ldots \ldots \ldots \ldots \ldots \ldots \ldots \ldots \ldots \ldots \ldots \ldots \ldots \ldots \ldots, 13$

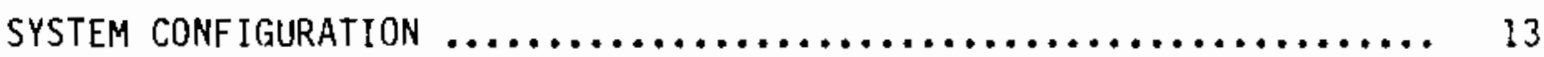

Temperature Control Algorithm $\ldots \ldots \ldots \ldots \ldots \ldots \ldots \ldots \ldots \ldots, 13$

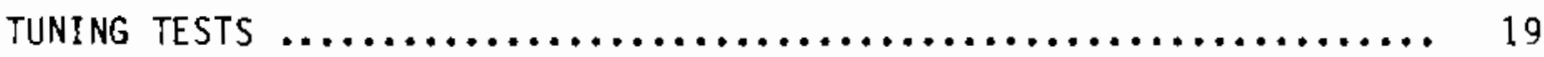

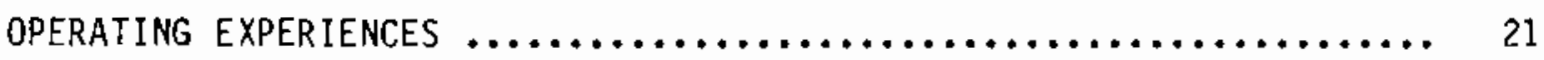

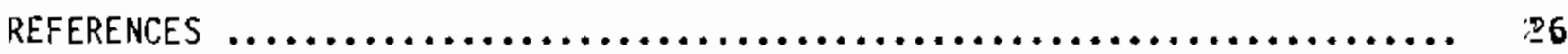




\section{FIGURES}

1 Cutaway Drawing of a Typical Liquid-Fed Ceramic Melter at PNL ....... 6

2 Electrode Power Control Circuits $\ldots \ldots \ldots \ldots \ldots \ldots \ldots \ldots \ldots \ldots \ldots \ldots$

3 Data Acquisition and Process Monitoring System ................. 14

4 Temperature Control Algorithm $\ldots \ldots \ldots \ldots \ldots \ldots \ldots \ldots \ldots \ldots \ldots \ldots \ldots \ldots$

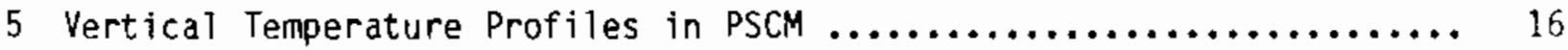

6 Multi-Point Recorder Tracing Showing Glass Temperatures During Foaming in PSCM-21 ................................... 18

7 Step Change in Power and Resulting Temperature Response .......... 20

8 Control Parameters for Proportional Control .................. 22

9 Control Parameters for PI Control $\ldots \ldots \ldots \ldots \ldots \ldots \ldots \ldots \ldots \ldots \ldots \ldots \ldots$

10 Control Parameters for PID Control $\ldots \ldots \ldots \ldots \ldots \ldots \ldots \ldots \ldots \ldots \ldots \ldots$

\section{TABLE}

1 Controller Parameters $\ldots \ldots \ldots \ldots \ldots \ldots \ldots \ldots \ldots \ldots \ldots \ldots \ldots \ldots \ldots \ldots \ldots \ldots . \ldots \ldots$ 
SUMMARY AND CONCLUSIONS

Control of the electrical power to the electrodes of liquid-fed ceramic melters (LFCM) is necessary to maintain glass temperatures at their optimum level such that a product of acceptable quality is produced, processing rates are maintained, and the equipment is operated safely and efficiently. Previous control systems have relied upon current, power, or resistance feedback control schemes to control power to the melter. Melter operators functioned as process controllers by adjusting the current, power, or resistance setpoint to maintain the glass temperatures within an acceptable range. Frequent adjustments were required during startup, shutdown, changes in feed rate and feed composition, and during glass foaming incidents.

Direct temperature feedback has not been implemented previousiy because of the concerns about the response to the failure of thermocouples used to measure the glass temperatures, and to the normal temperature fluctuations associated with convective currents in the glass.

A temperature feedback control system that overcomes these problems has been developed for controlling electrical power to the LFCM. Glass temperatures are processed by a microcomputer, and a power setpoint is sent to the power feedback process controller. This temperature control algorithm effectively completes the control function previously performed by the meiter operators. The algorithm includes steps to 1) reject thermocouples that do not appear to be functioning, 2) average the glass temperatures measured at different locations in the melter, 3) smooth the spatially averaged glass temperature to reduce the magnitude of the temperature oscillations, and 4) determine if the glass may be foaming and take corrective action if desired.

The temperature control system has been tested during five melter experiments including two different melters at the Pacific Northwest Laboratory (PNL). Three control modes--proportional (P), proportional-integral (PI), and proportional-integral-derivative (PID) were evaluated. All three control modes provided acceptable control during steady-state operation. The PI control mode provided the best control during all phases of melter operation including startup, steady-state operation, intentional and unintentional feed stoppage, 
and idling. At the time of this writing, the control logic is being implemented on distributed control systems for radioactive melters at PNL and West Valley Nuclear Services. 


\section{INTRODUCTION}

The U.S. Department of Energy (USDOE) is funding several programs designed to treat high-level radioactive wastes by immobilizing the wastes in a glass imatrix. The reference process for converting these liquid wastes into glass is the liquid-fed ceramic melter (LFCM) process. The Nuclear Waste Treatment Program at Pacific Northwest Laboratory (PNL), has the responsibility for managing civilian nuclear waste programs in the United States. One objective of the program is to complete the development of the LFCM process and transfer the technology to sites that generate high-level waste (HLW) including Savannah River, South Carolina; West Valley, New York; and Hanford, Washington. Among the remaining development activities is to complete the process control methods for the vitrification process.

In the LFCM process, a slurry of the radioactive wastes and glass-forming chemicals is poured onto a pool of molten glass within the glass meiter. Heat from the molten glass dries the slurry and converts the chemicals to their oxides, which then melt, forming additional glass in the melter. Periodically, glass is poured from the melter into large metal canisters where the glass cools and is stored prior to being shipped to a repository for final disposal.

The energy needed to dry, calcine, and melt the wastes is provided by passing an alternating electrical current through the molten glass, where the electrical resistivity of the glass generates the heat needed for the process. Operation of the LFCM requires that the electrical power to the melter be controlled such that the glass temperatures are maintained at their optimum level to produce a product of required quality, to maintain acceptable processing rates, and to operate the processing equipment safely. In a typical LFCM installation, the power to the melter is controlled using resistance, power, or current feedback to the power controller. The operator adjusts the controller setpoint such that the glass temperatures in the melter are within an acceptable operating range. Direct temperature feedback control of the melter power has not been used because of concerns about 1) the long-term reliability of individual thermocouples, 2) the response of the controller to the temperature fluctuations associated with convective currents in the glass, 
and 3) the difficulties in tuning a control loop that includes the melter with its long response time.

PNL has developed a temperature control system that automatically adjusts the power to the melter to maintain the glass temperatures within an acceptable range. The temperature-control system overcomes the concerns listed above that have precluded using temperature feedback control in the past. In the following sections, the LFCM process and the melter and power supply configuration are described in more detai1, the features of the temperature control system are presented, and the operating experience with the control system is discussed. 


\section{DESCRIPTION OF THE LFCM PROCESS}

The objective of the LFCM process is to convert an aqueous slurry containing radioactive wastes into a glassy solid within a metal canister. This conversion is accomplished in the glass melter. In this section, the PNL glass melters and their power supply systems are discussed, particularly with respect to controlling power to the melter. Resistance, power, and current feedback methods for controlling the power are compared.

\section{MELTER SYSTEMS}

The slurry fed to the glass melter is a mixture of radioactive wastes and glass-forming chemicals and/or a finely crushed glass frit. This mixture is formulated to yield a glass of known composition and properties after it is processed through the melter. The glass has been designed to have acceptable properties for both processing and disposal as the final waste form. Of primary concern here are the processing properties of the glass. Because of the materials used to withstand the chemical, thermal, and radiation environment in the melter tank, and because the glass quality decreases as the melting temperature decreases, the operating temperature range for the melter is limited to 1075 to $1200^{\circ} \mathrm{C}$. The glass is formulated to have a viscosity of 100 poise in this temperature range and has an electrical conductivity of between 0.18 and $0.50(\mathrm{ohm} \mathrm{cm})^{-1}$. Additional considerations in formulating the slurry are providing a slurry with acceptable rheological properties and controlling the redox state of the glass to inhibit a phenomenon known as reboil or foaming, where a change in redox potential releases oxygen from the glass and forms a foam on the glass surface (Goldman, Brite, and Richey 1984).

Figure 1 shows a cutaway drawing of a typical PNL glass melter. The rectangular melter cavity is lined with a corrosion-resistant refractory. Two Inconel 690 slab electrodes are located opposite each other on the short walls of the melter cavity. Low on a long wall, between the two electrodes, is the entrance to the glass riser, which is used for transferring glass from the

(3) Inconel is a registered trademark of the International Nickel Company, Inc. 


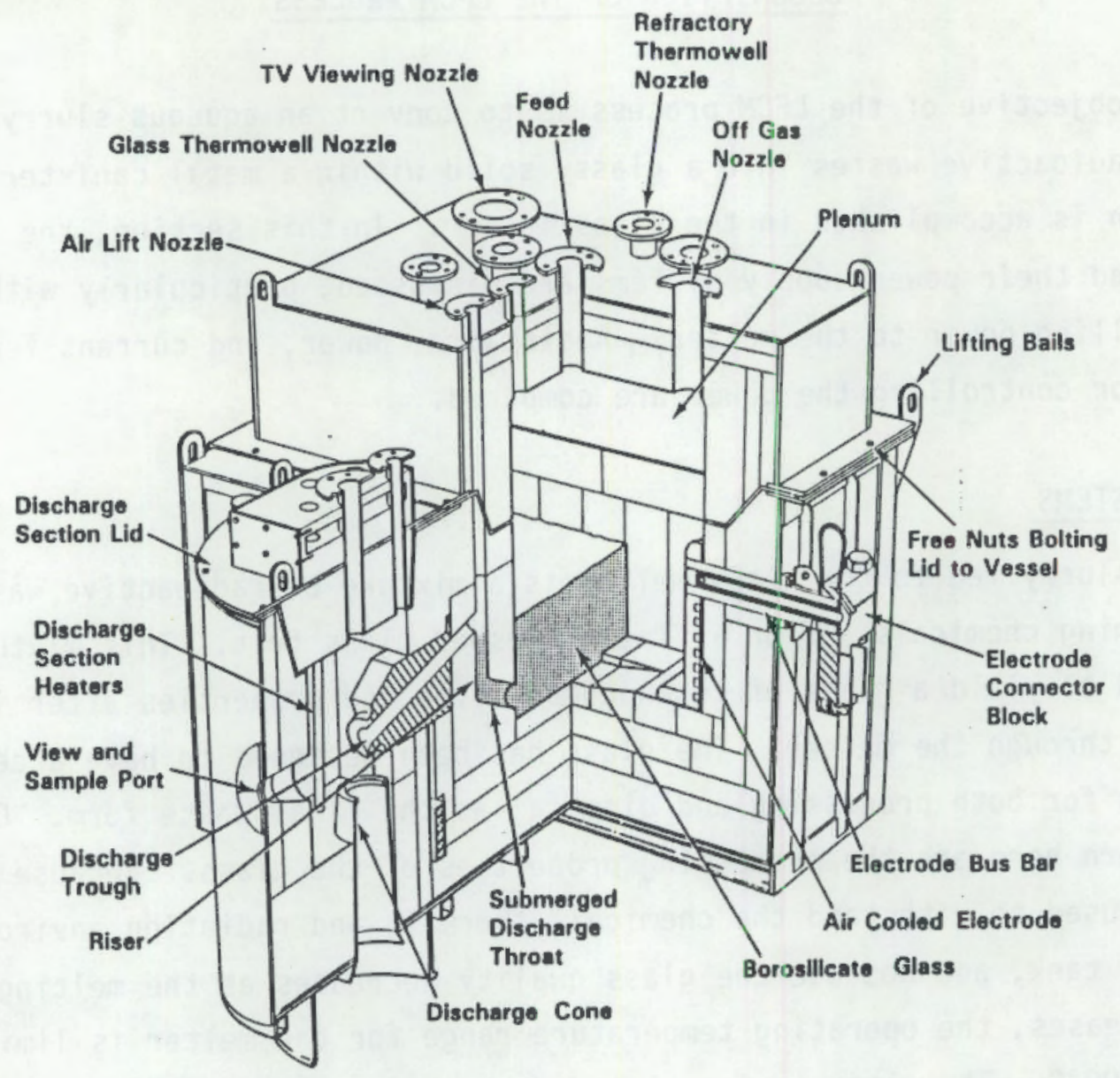

FIGURE 1. Cutaway Drawing of a Typical Liquid-Fed Ceramic Melter at PNL

melter through the glass discharge section and into the canister located beneath the melter. The discharge section is heated by silicon carbide resistance heaters. This report addresses only control of power to the main melter electrodes, not to the discharge section heaters.

Instrumentation used for monitoring and control of the melting process includes thermocouples, a glass level-detection device (pneumatic bubbler tubes), and a viewport and/or TV camera for looking onto the glass surface (Westsik et al. 1985). Type $K$ or Type B thermocouples in a 2.5-cm-diameter by D.64-cm-thick wall Inconel 690 thermowell are used to monitor the glass temperatures. Type $K$ thermocouples are typically used because of their lower cost. The thermocouples are located below the glass level, in the cold cap region just above the glass surface (discussed below), and in the plenum above the 
melt. Type $K$ thermocouples are recognized to have a short lifespan (< one year) at normal molten glass temperatures $\left(\sim 1150^{\circ} \mathrm{C}\right)$. Therefore, replacement of the thermocouples must be a scheduled maintenance activity.

During normal operations, the feed slurry is pumped at a controlled rate onto the molten glass surface in the melter cavity. At sufficiently high feed rates, a cold cap forms on the surface. It is in this cold cap region that the slurry dries and the wastes and glass-formers are converted to their oxides before melting to form additional glass. When the glass level in the melter is high enough that glass begins to flow over the overflow and into the canister, the glass flow rate is increased using an airlift system. Two to five centimeters of glass ( 7 to $17 \%$ of the glass volume) are removed from the melter during each batch pour before the glass transfer is stopped. Feed is continuously added to the melter such that the glass level rises again and the cycle is repeated.

The temperature control system has been used with two different melters at PNL. The smaller melter, known as the High-Bay Ceramic Melter (HBCM) has an exposed glass surface of $0.25 \mathrm{~m}^{2}$ and a maximum glass height of $21.6 \mathrm{~cm}$, for a total glass volume of 55 liters. Typical slurry processing rates for the HBCM are in the range of 15 to $20 \mathrm{~L} / \mathrm{h}$. The larger melter is known as the PilotScale Ceramic Melter (PSCM). It has an exposed glass surface of $0.73 \mathrm{~m}^{2}$ and a maximum glass depth of $38 \mathrm{~cm}$. This corresponds to a glass volume of 280 liters (Perez and Nakaoka 1985).

\section{POWER CONTROL SYSTEMS}

The electrode power circuits for the HBCM and PSCM are shown in Figure 2. The power is regulated by proportional, phase-angle controlled, silicon-controlled rectifier (SCR) power controllers, which include current limiters as an added safety feature (Dierks 1980). The control signal to the power controller is provided by a separate process controller. Direct feedback to the process controller can be current, power, voltage, resistance, or temperature.

Voltage feedback control has not been used because it is inherently unstable. As the glass temperature increases, the resistance drops and the current 


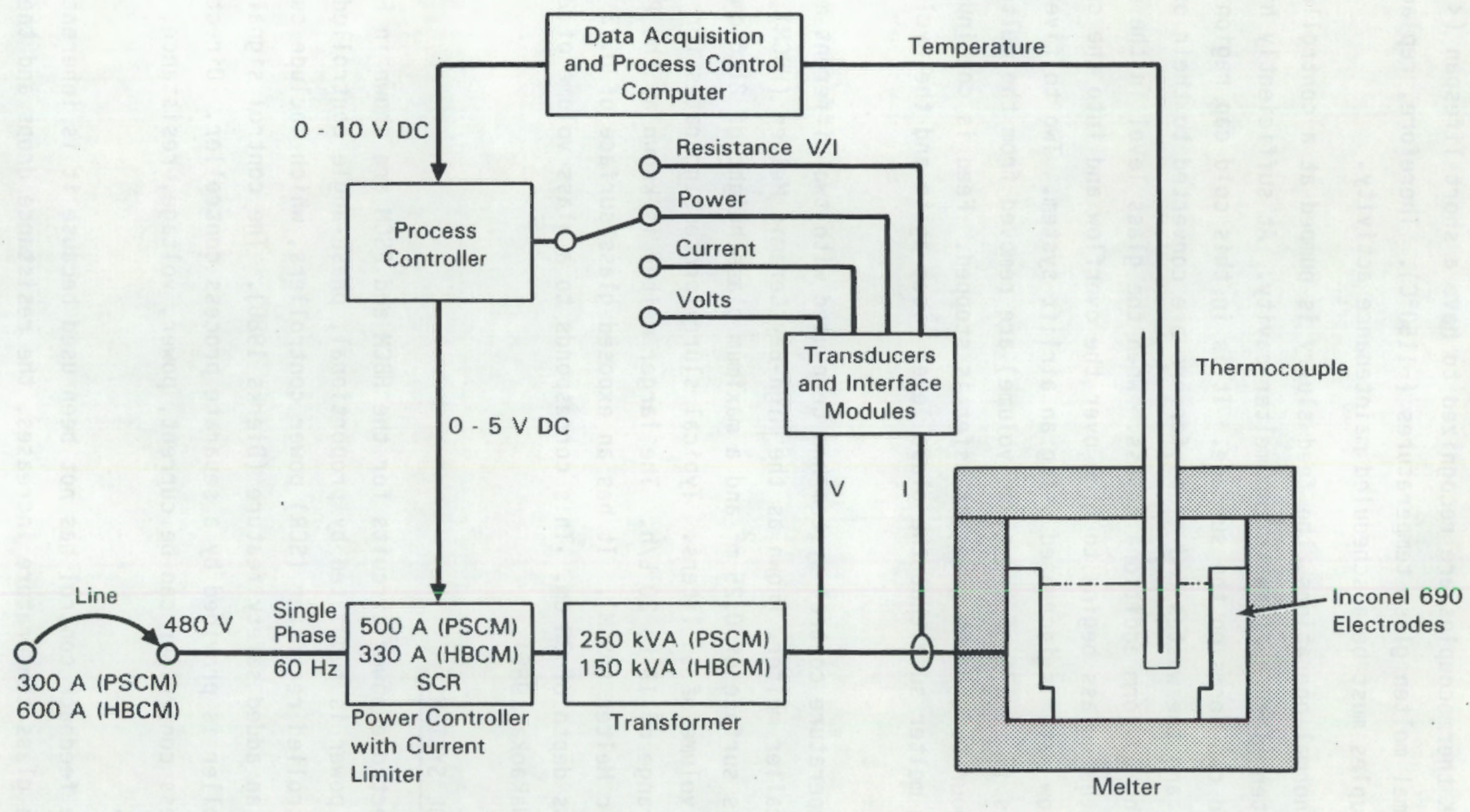

FIGURE 2. Electrode Power Control Circuits 
increases to maintain the constant voltage. Increasing the current increases the power that is dissipated in the glass, which then further increases the glass temperature.

Direct temperature feedback has not been used in the past for several reasons. First, because the Type $K$ thermocouples used to measure the glass temperatures are operating at the upper end of their recommended range $(-200$ to $\left.1260^{\circ} \mathrm{C}\right)$ and because relatively thin thermocouples wires $(0.051-\mathrm{cm}$ diameter in 0.32-cm-diameter sheath) are used in this environment, the thermocouples are susceptible to drift and ultimately failure (ASTM 1981). Experience at PNL indicates that lifetimes of six months or less should be expected. Second, temperature gradients in the glass induce convection currents such that, over a 15-minute period, temperature fluctuations at a point in the melter can have a range of as much as $\pm 20^{\circ} \mathrm{C}$ around the average temperature. Finally, the melter's long response time to changes in power or load makes tuning the control loop difficult (Chapman 1980). Therefore, prior to development of the temperature control algorithm, current, power, or resistance feedback were used to control power to the melter.

Resistance feedback control is attractive because, within the normal operating temperature range, the glass resistivity is approximately inversely proportional to the glass temperature. Thus, as the glass temperature drops due to changes in feed rate, for example, the resistance increases and the controller demands more power to bring the temperatures back into range. Resistance feedback control has worked well when glass is poured continuously from the melter. However, a drawback of resistance feedback control is the fact that when the melter is operated in a batch-pour mode, the changes in glass level change the resistance through the glass, which causes unnecessary fluctuations in the power to the melter. Another drawback is the fact that the glass resistance is also dependent upon the composition of the glass. The resistance of some glass compositions is more sensitive to temperature than others; therefore, some glass compositions may not be amenable to resistance feedback control (Chapman 1980). 
Current feedback control was recommended in the past as the best configuration for controlling power to the melter (Chapman 1980; Plodinec and Chismar 1980; Weisenburger 1980). Power (P) dissipated in the melter is proportional to the current (I) and resistance (R):

$$
P=I^{2} R
$$

Therefore, with current feedback control, as the temperature decreases in the melter due to an increase in the feed rate, the amount of power dissipated increases because of the increase in resistance. Similarly, as the temperature increases, the amount of power dissipated decreases. Thus, current feedback control is inherently self-correcting for small temperature variations. Current feedback control suffers the same drawbacks as resistance feedback control, including dependence upon the glass composition and the glass level in the melter. Furthermore, current feedback control cannot respond to larger changes in load such as startup, shutdown, or inadvertent loss of feed to the melter and, in these situations, requires that the operator make frequent adjustments in the setpoint. Consequently, while current feedback control was used during the initial development of the LFCM process at PNL, it has not been used extensively at PNL.

Perhaps the most significant drawback to using resistance or current feedback control is the fact that some glass compositions are susceptible to a phenomenon known as reboil or foaming. A change in the redox state in the glass causes the release of oxygen, which forms a foam or scum between the glass and the cold cap (Goldman, Brite, and Richey 1984). Heat transfer to the cold cap is inhibited by the foam and the glass temperature increases. Because foaming appears to be caused, in part, by an increase in the glass temperature, the problem is accentuated. Foaming also increases the resistance of the glass; so, despite the already increasing temperatures, more power is sent to the melter, further exacerbating the problem.

Power feedback control works well during steady-state operations and is not susceptible to the changes in glass level associated with batch glass transfers from the melter. While power feedback does not reduce the power in 
response to foaming (the appropriate corrective action), it does not increase the power levels as current and resistance feedback control modes do. On the other hand, because power is not directly related to glass temperature, melter operators typically make more setpoint adjustments during steady operation in this mode than with current or resistance feedback control. As with current feedback mode, power feedback requires frequent setpoint changes during startup, shutdown, and loss of feed.

It must be recognized that, though resistance, current, and power feedback control are discussed above, g.lass temperature is the processing parameter that is finally being controlled. Melter operators function as process controllers by adjusting the resistance, power, or current setpoint in response to unacceptable changes in the indicated glass temperature and to changes in processing conditions. An automatic temperature control system is desired that can respond to these changes faster and more effectively than the operators can. 

Temperature control has always been used in operating liquid-fed ceramic meiters; the controller has been the human operator rather than a mechanical or electronic device. Certainly, temperature could have been used directly as the feedback mode to the process controller shown in Figure 2. However, concerns about the response to the loss of thermocouples and to the normal temperature fluctuation associated with convective currents in the glass have prevented the use of direct temperature feedback control. Digital computers and microprocessors can be used to implement more sophisticated control schemes such that temperature feedback has been used successfully to control electrical power to the melter.

\section{SYSTEM CONF IGURATION}

The temperature control system developed at PNL centers around a Hewlett Packard (HP) microcomputer and data acquisition system shown in Figure 3. Glass temperatures are processed by the computer and a power setpoint is sent to the process controller as shown in Figure 2. The process controller provides proportional-integral-derivative (PID) control of the power at that setpoint until a new setpoint signal is received from the HP system.

Temperature Control Algorithm

Figure 4 shows the temperature control algorithm logic. The algorithm is implemented on the HP computer as several subroutines in a large program, written in the BASIC programming language, used for data acquisition and process monitoring.

To resolve the concern about failed thermocouples, the algorithm begins by verifying that the thermocouples are functioning; i.e., they have not shorted or broken. Glass temperatures are checked to determine if they are in the range of 1000 to $1250^{\circ} \mathrm{C}$; any temperature measurements outside that range are considered to be an indication of a failed thermocouple. A message is printed identifying which thermocouple has failed, and the temperature measurement is ignored in the succeeding steps of the algorithm. 


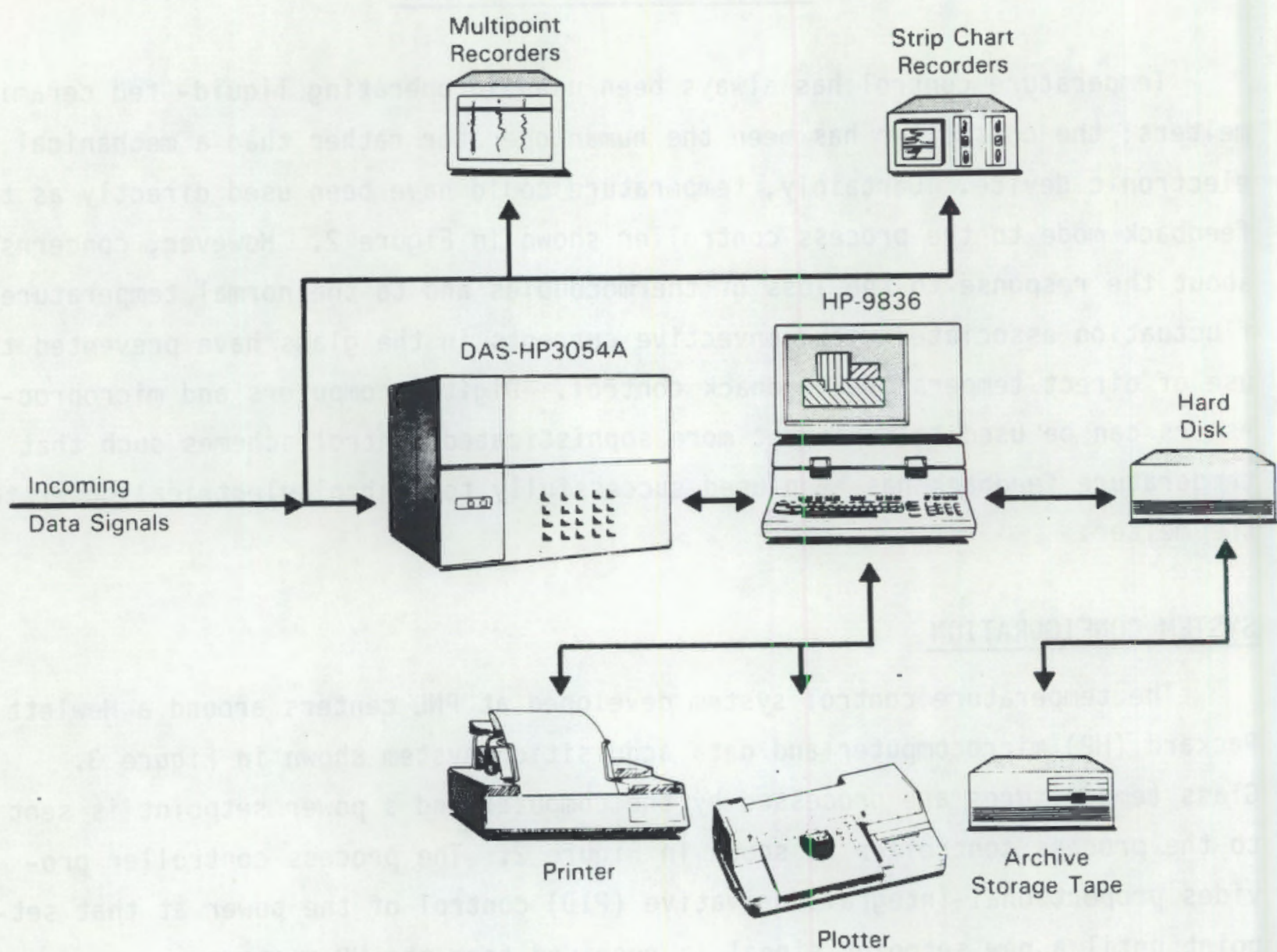

FIGURE 3. Data Acquisition and Process Monitoring System

The algorithm then calculates the arithmetic average glass temperature as measured by the functioning thermocouples. Typically there are three to five thermocouples located in the molten glass pool. As Figure 5 shows, there is a vertical temperature profile in the glass. Thermocouples near the floor of the melter or near the cold cap are not included in the average because of their proximity to colder surfaces.

When the temperature control algorithm was first conceived, the spatially averaged temperatures were to be averaged over a specific time period. When a melter operator functions as the temperature controller, he or she looks at a strip chart that shows the glass temperature, mentally estimates a temperature average over a period to time, and adjusts the process controller accordingly. The moving time average calculated by the computer would effectively 


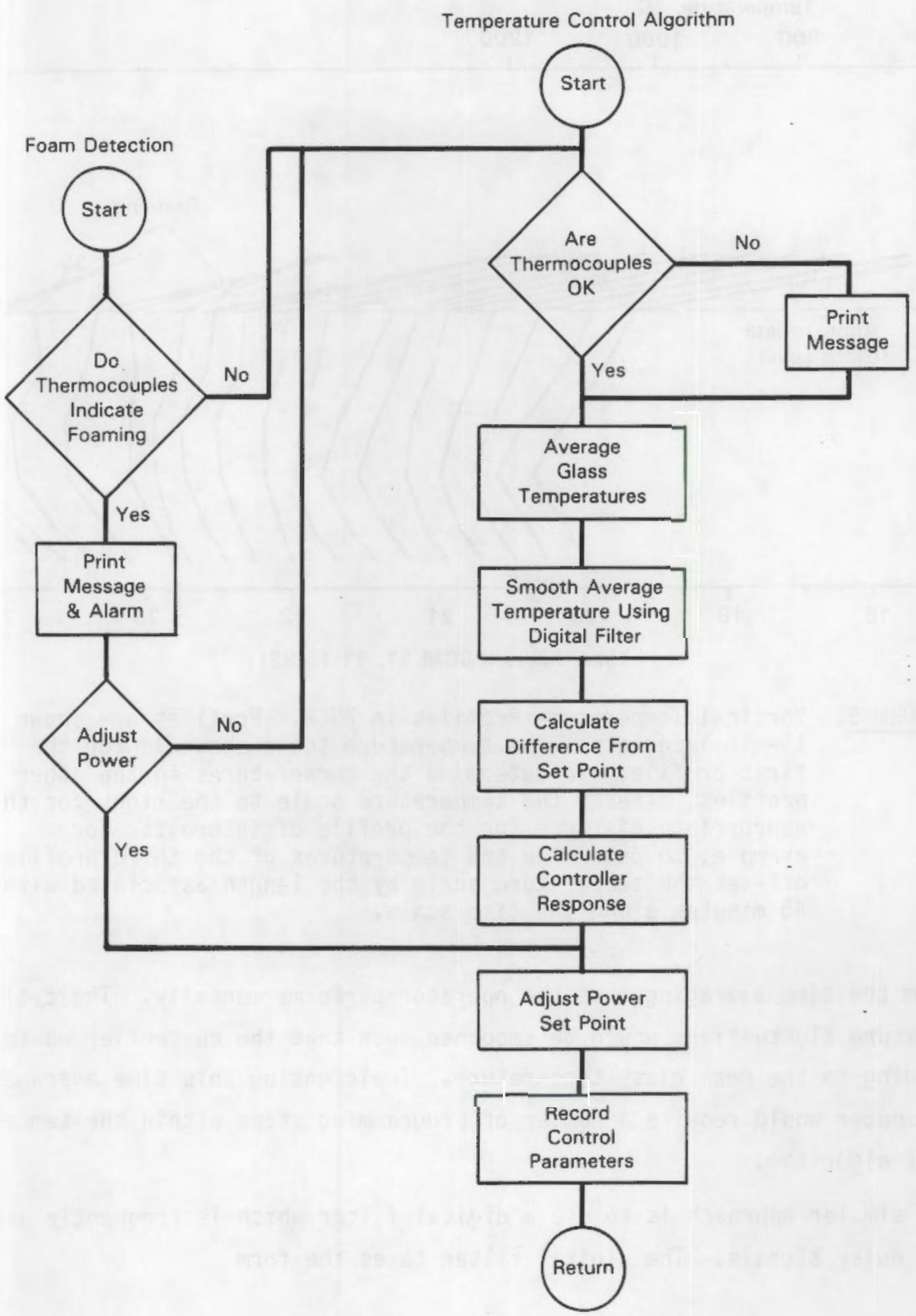

FIGURE 4. Temperature Control Algorithm 


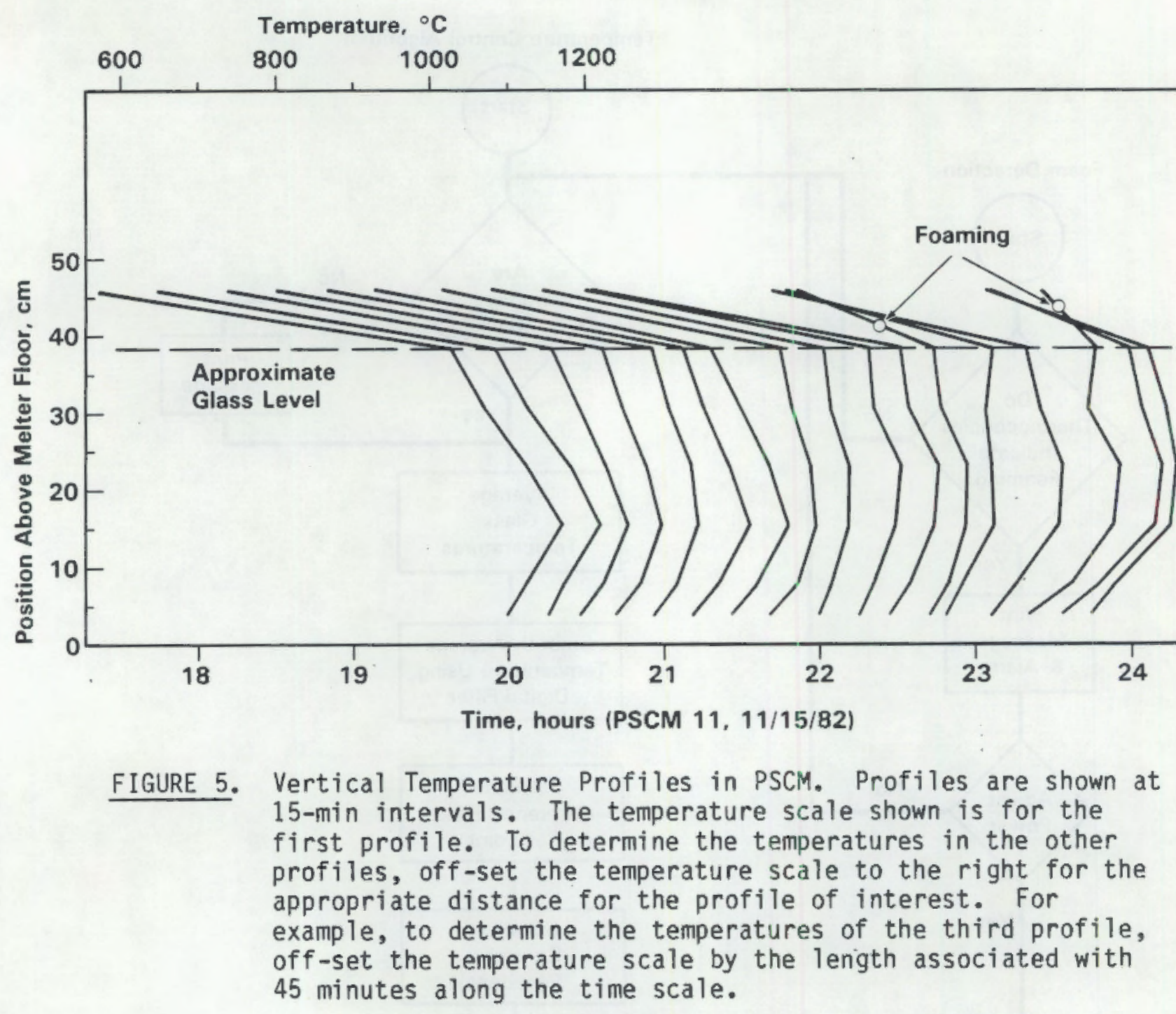

perform the time averaging that the operator performs mentally. The cyclic temperature fluctuations would be smoothed such that the controller would be responding to the mean glass temperature. Implementing this time average on the computer would require a number of programming steps within the temperature control algorithm.

A simpler approach is to use a digital filter which is frequently used to smooth noisy signals. The digital filter takes the form

$$
T_{f n}=\left(1-\frac{1}{Q}\right) T_{f(n-1)}+\frac{1}{Q} T_{\text {(ave) }}
$$


where $T_{f n}=$ the smoothed temperature

$T_{f(n-1)}=$ the previous smoothed temperature

$T_{\text {(ave) }}=$ the spatially averaged glass temperature

$Q=$ the ratio of the digital filter time constant ( $t$ ) to the sampling period $\left(t_{s}\right)$. The sampling period is the interval (one minute) between scans of the data acquisition system.

As discussed below, the digital filter time constant can be estimated from the process dynamics. Increasing $Q$ increases the degree of smoothing.

The algorithm then compares the spatially averaged and smoothed temperature with the temperature setpoint and calculates a response using traditional controller modes--proportional (P), integral (I), and derivative (D). As discussed below, three control modes, P, PI, and PID, have been tested, and PI has proved to be the most functional for this application.

Finally, the calculated response is relayed to the process controller, which uses the signal as a new power setpoint.

To detect foaming, the algorithm looks at temperatures measured by thermocouples just above the glass surface in the region of the cold cap. These temperatures will always be below the glass temperatures unless foaming occurs and the glass level rises above these thermocouples (see figure 6). Therefore, as long as the temperatures are below operator-specified foam-detection temperatures, the algorithm takes no action. However, if the temperatures in the cold cap region exceed the foam-detection temperatures, then foam may be present in the melter. In this case, the algorithm sends a message to the printer, issues an alarm, and if desired, reduces the electrode power to some lower level.

The foam-detection temperatures are set 50 degrees above the temperatures measured by the thermocouples in the cold cap region when the melter is idling $\left(1050\right.$ to $1100^{\circ} \mathrm{C}$ ) but no higher than the desired operating glass temperature (i.e., $1150^{\circ} \mathrm{C}$ ). Normal operating temperatures will be 400 to $900^{\circ} \mathrm{C}$ for these thermocouples. With the detection temperatures set above $1050^{\circ} \mathrm{C}$ the algorithm will not give a false foaming indication when the feed is off and the cold cap is consumed. 


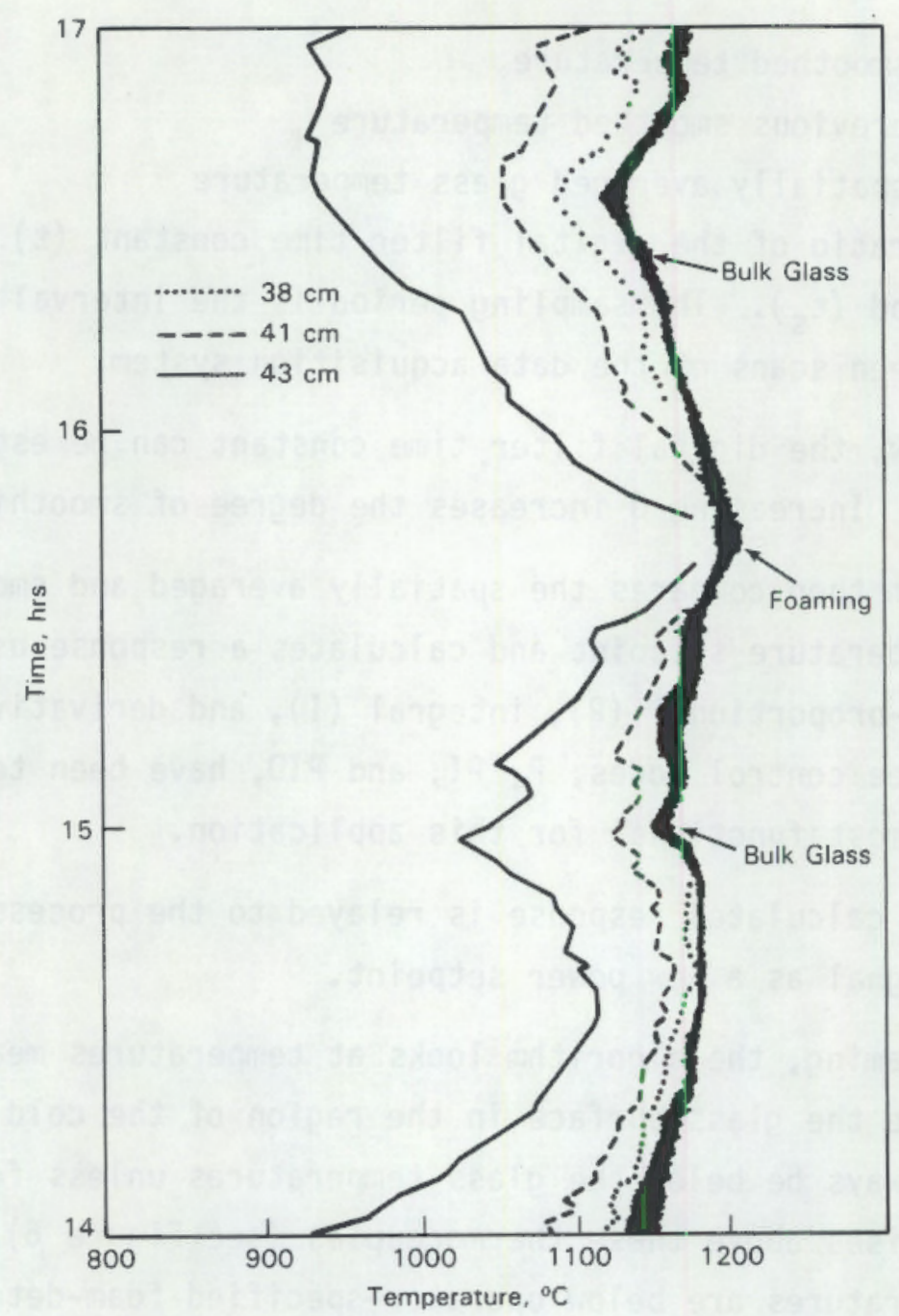

FIGURE 6. Multi-Point Recorder Tracing Showing Glass Temperatures During Foaming in PSCM-21

Two features intended to emulate melter operator control actions were initially incorporated into the algorithm but were determined to be a hindrance to effective control. One was to introduce a time interval between changes in the power setpoint so that the melter would have some time to respond to each power change. The other was to change the power setpoint only when the temperatures were outside an acceptable range $\left( \pm 10\right.$ to $\left.15^{\circ} \mathrm{C}\right)$ around the temperature setpoint. In each case, the power changes tended to be larger, and the temperature control was not as good as it was without these features. 
TUNING TESTS

Tuning a controller requires determining values for the proportional gain and the integral, derivative and digital filter time constants such that the desired control is achieved. Concern for tuning temperatures controllers for liquid-fed ceramic melters with their long response times has been a hindrance to the application of direct temperature feedback control to the LFCM process.

We used the empirical process reaction curve method of Cohen and Coon (1953; Coughanowr and Koppel 1965; Stephanopoulos 1984) to determine the initial values of the proportional gain and integral and derivative time constants for the temperature control algorithm. In the process reaction curve method, a step change is made in the input to the process and the open loop response is recorded over time. The process is assumed to be a first order system with dead time, and the coefficients for the equation describing the process can easily be determined from the process reaction cure. Cohen and Coon derived expressions for the controller settings in terms of the process equation coefficients such that controller performance criteria including one-quarter decay ratio and minimum offset would be met.

To obtain the process reaction curve for the PNL melters, step changes in power were made and the resulting changes in temperature were recorded over time. Step changes were made when the melters were idling and when feed was being processed. Only idling conditions yielded clearly defined reaction curves. Figure 7 shows the temperature response of the HBCM to a power increase of $0.75 \mathrm{~kW}$. The constructions used to determine the initial and final temperatures, the slope of the curve at the inflection point, and the time delay are also shown. These values are needed to determine the coefficients of the process equation. The resulting controller parameters are shown in Table 1 along with the resuits of similar tests conducted with the PSCM.

During actual operation, the proportional gains were found to be too large, in part because of the temperature fluctuations around the temperature average. The proportional gains were therefore reduced to a level where acceptable control was achieved. The integral and derivative time constants were not changed. 


\begin{tabular}{|c|c|c|c|c|c|c|}
\hline \multirow[b]{2}{*}{$\begin{array}{c}\text { Control } \\
\text { Mode } \\
\end{array}$} & \multicolumn{3}{|c|}{$\mathrm{HBCM}$} & \multicolumn{3}{|c|}{ PSCM } \\
\hline & $\begin{array}{c}\text { Proportional } \\
\text { Gain } \\
\left(\mathrm{kW} /{ }^{\circ} \mathrm{C}\right) \\
\end{array}$ & $\begin{array}{l}\text { Integral } \\
\text { Time } \\
\text { Constant } \\
\text { (s) } \\
\end{array}$ & $\begin{array}{c}\text { Derivative } \\
\text { Time } \\
\text { Constant } \\
\text { (s) } \\
\end{array}$ & $\begin{array}{c}\text { Proportional } \\
\text { Gain } \\
\left(\mathrm{kW} /{ }^{\circ} \mathrm{C}\right) \\
\end{array}$ & $\begin{array}{c}\text { Integral } \\
\text { Time } \\
\text { Constant } \\
\text { (s) } \\
\end{array}$ & $\begin{array}{c}\text { Derivative } \\
\text { Time } \\
\text { Constant } \\
\text { (s) }\end{array}$ \\
\hline$P$ & 0.41 & & & 2.1 & & \\
\hline PI & 0.36 & 2400 & & 1.8 & 1800 & \\
\hline PID & 0.53 & 2200 & 340 & 2.7 & 1700 & 260 \\
\hline
\end{tabular}

(a) Based upon step changes in power while the melter was idling and using the method of Cohen and Coon (1953).

The digital filter time constant can be estimated from the integral and derivative time constants for the controller (Goff 1966). For PI control, the rule-of-thumb is that the filter constant should be $1 / 4$ to $1 / 12$ of the integral time constant depending upon the dead time. For PIO control, the digital filter time constant should be $1 / 10$ to $1 / 20$ of the derivative time constant to retain the benefits of the derivative control function. During testing with the PNL melters, digital filter time constants of one and three minutes were used with $P$ and PIO control and a value of five minutes was used with PI control. Adequate control was obtained with all three values. The smaller the value of the time constant, the quicker the response to changes in temperature and the larger the oscillations in power during steady operation. Because the response time was satisfactory with the larger time constants, they are preferred.

\section{OPERATING EXPERIENCES}

The temperature control system has been tested during five melter runs including two PSCM and three HBCM runs. During each run, different combinations of control mode (P, PI, PID), digital filter time constant, controller scan frequency, and acceptable temperature range were tested. Figures 8 through 10 show some typical control data for each of the control modes and two digital filter time constants (one and five minutes). 

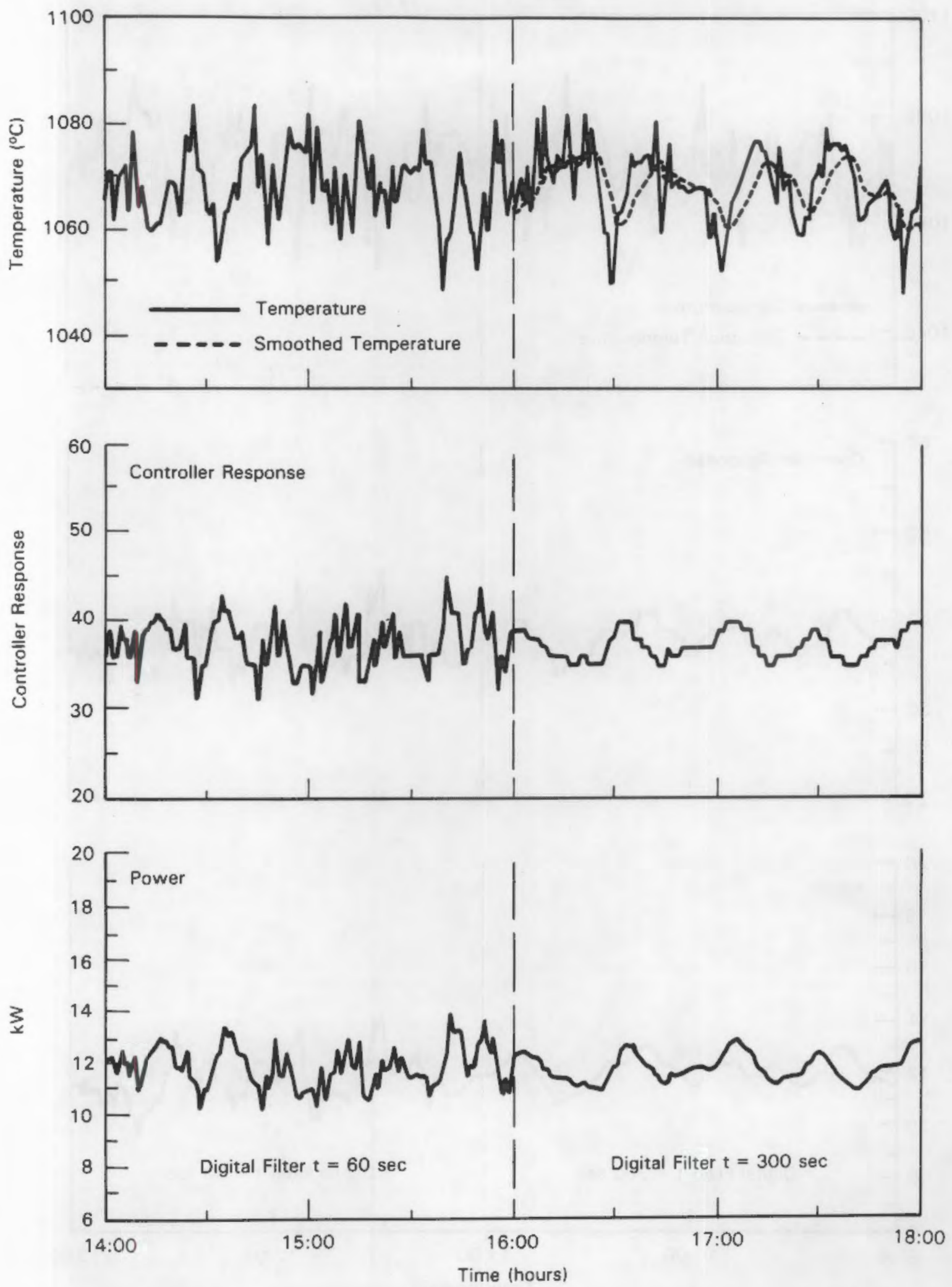

FIGURE 8. Control Parameters for Proportional Control 

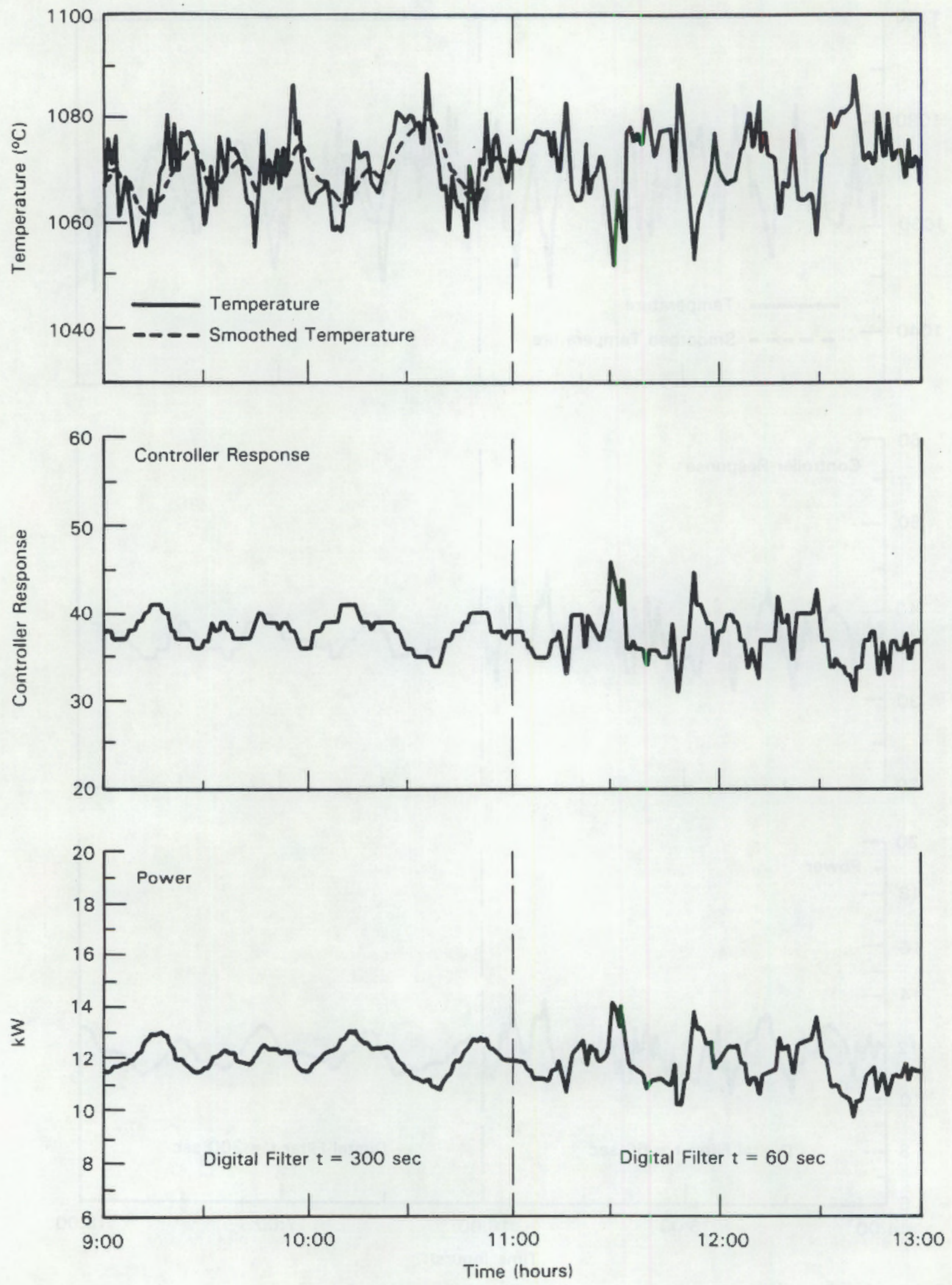

FIGURE 9. Control Parameters for PI Control 

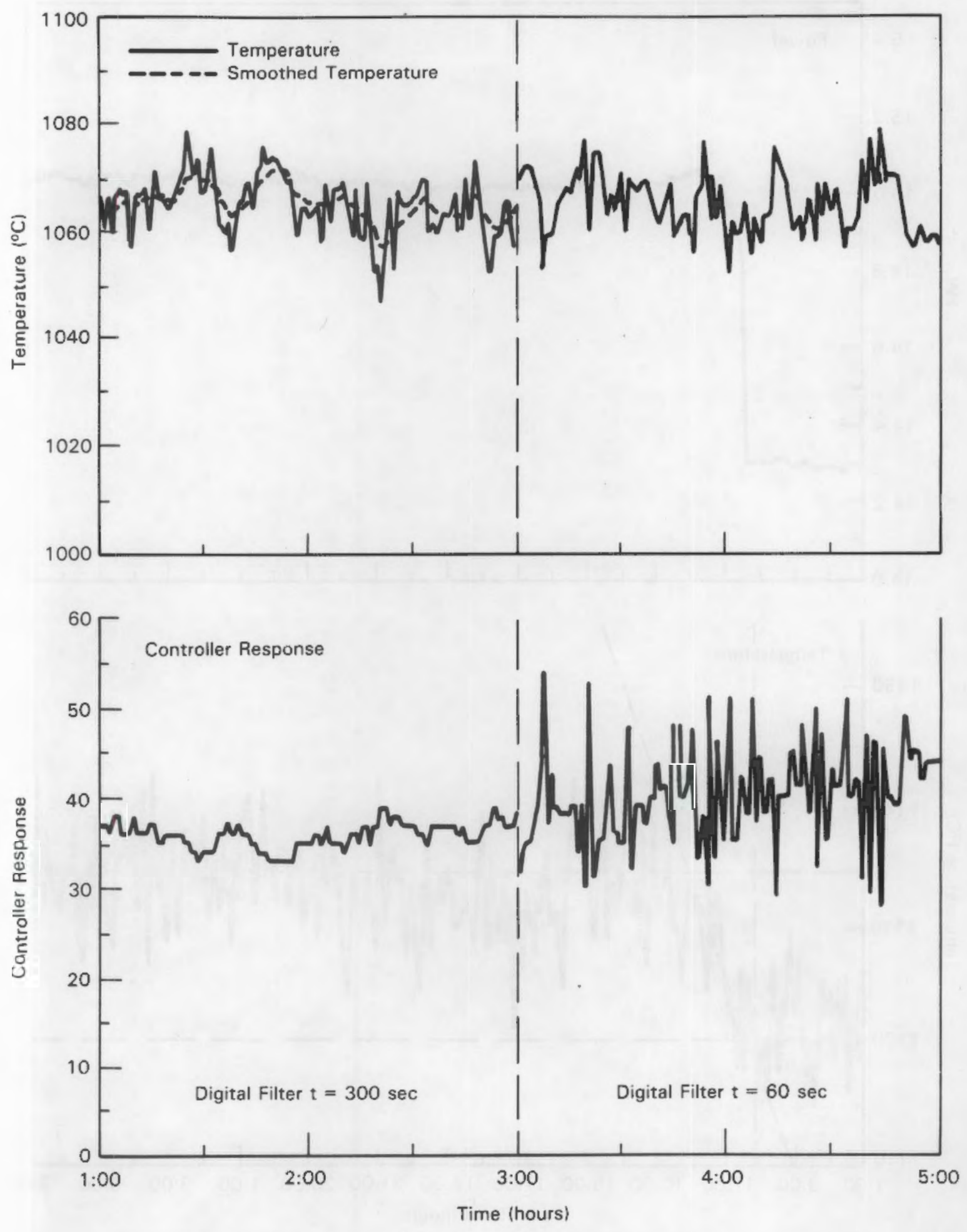

FIGURE 10. Control Parameters for PID Control 

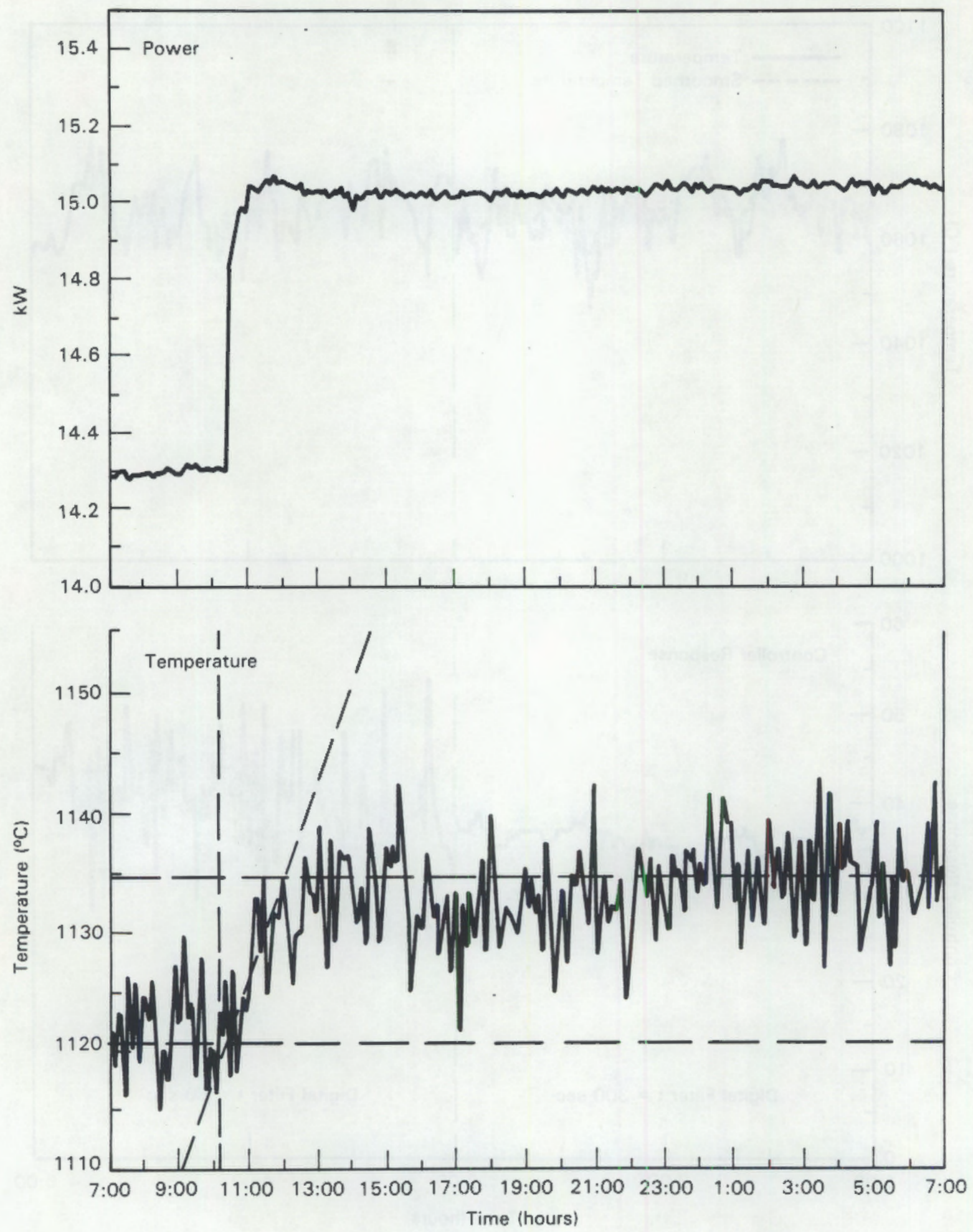

FIGURE 7. Step Change in Power and Resulting Temperature Response 
Proportional control was tested first because it is least likely to introduce instability to the process. This control mode worked well during steadystate operations but did not respond well to transients associated with starting and stopping feeding and with foaming incidents. This is typical of proportional control, which is characterized by the production of an offset or nonzero steady-state error. The foam-detection method was conceived during this first experiment and so was not available for testing. No glass compositions since this first one have foamed so the foam-detection feature remains untested.

PID control was tested during the next three melter experiments because the integral component eliminates the offset observed with proportional control and the derivative component has a stabilizing effect on the process. The PID control mode provided good control of the glass temperatures during all phases of melter operation, including startup, steady-state operation, and intentional and unintentional feed stoppages. The meiter operators simply monitored the temperatures and power levels and did not need to make changes.

The derivative or rate component of the PID control was found to be largely ineffective in this application. The process time constant for the change in glass temperature to a change in power is on the order of hours. Normal temperature fluctuations in the glass have a period on the order of 5 to 20 minutes. Despite the smoothing of the average temperatures provided by the digital filter, unnecessary and large power adjustments were produced due to the oscillations superimposed on the longer term trend in the glass temperatures (see Figure 10).

The fifth melter run used the PI control mode with a larger digital filter time constant (five minutes). Removing the derivative component of the controller reduced the magnitude of the power changes and the stability of the process was maintained. This configuration worked well during all phases of the run, including startup and shutdown, steady operation, changes in feed rate and feed composition, and during idling. Based on these experiences, PI is the preferred control mode for temperature feedback control of the LFCM process. 
REFERENCES

American Society for Testing and Materials (ASTM). 1981. Manual on the Use of Thermocouples in Temperature Measurement. American Society for Testing and Materials, Philadelphia, Pennsylvania.

Chapman, C. C. 1980. "Nuclear Waste Glass Melter Jesign Including the Power and Control Systems." In proceedings of IAS Annual Meeting 1980, IEEE Industry Applications Society, New York.

Cohen, G. H., and G. A. Coon. 1953. Trans. ASME. 75:827.

Coughanowr, D. R., and L. B. Koppe1. 1965. Process Systems Analys is and Control. McGraw-Hill, Inc., New York.

Dierks, R. D. 1980. "The Design and Operation of a 10D-kg/h Electric Melter for Nuclear Waste Vitrification." In IAS Annual Meeting 1980, IEEE Industry Applications Society, New York.

Goff, K. W. 1966. ISA Journal. 13:45.

Goldman, D. S., D. W. Brite and W. C. Richey. 1985. "Investigation of Foaming in Liquid-Fed Melting of Simulated Nuclear Waste Glass." PNL-SA-2211, presented at the American Ceramic Society Annual Meeting, April 21: - May 3, 1984, Pittsburgh.

Perez, J. M., Jr., and R. K. Nakaoka. 1986. "Vitrification Testing of Simulated High-Level Radioactive Waste from Hanford." In proceedings of Waste Management 86, University of Arizona, Tucson.

Plodinec, M. J., and P. H. Chismar. 1980. "Design and Operation of SmallScale Glass Melters for Immobilizing Radioactive Waste." In proceedings of IAS Annual Meeting 1980, IEEE Industry Applications Society, New York.

Stephanopoulos, G. 1984. Chemical Process Control. Prentice-Ha11, Inc., Englewood Cliffs, New Jersey.

Weisenburger, S. 1980. "Nuclear Waste Vitrification in a Ceramic-Lined Electric Glass Melter." In proceedings of IAS Annual Meeting 1980, IEEE Industry Applications Society, New York.

Westsik, J. H., et al. 1985. Instrumentation for Remote Monitoring of LiquidFed Ceramic Melters. PNL-5635, Pacific Northwest Laboratory, Richland, Washington. 


\section{DISTRIBUTION}

No. of

Copies

OFFSITE

30 DOE Technical Information Center

6 Geologic Repository Division DOE Office of Civilian Radioactive Waste Management Forrestal Building Washington, DC 20585

ATTN: C. R. Cooley, RW-4

J. R. Hilley

W. J. Purcell, RW-20

B. C. Rusche, $R W-1$

D. E. Shelor

R. Stein, RW-23

3 DUE Office of Defense Waste \& Byproducts Management

$$
\text { GTN }
$$

Washington, DC 20545

ATTN: R. K. Heusser

J. E. Lytie, DP-12

R. D. Walton, Jr., DP -123

6 DOE Office of Terminal Waste GTN

Washington, DC 20545

ATTN: J. A. Coleman, NE -25

T. W. McIntosh, NE -25

H. Stelling, NE-25

W. R. Voigt, NE-20

H. F. Walter, NE-25

J. B. Zorn, NE-25

A. T. Clark

Division of Fuel Material Safety

Nuclear Regulatory Commission Washington, DC 20555
No. of

Copies

V. Stello

Office of the Executive Director for Operations

Mail Station 6209

Nuclear Regulatory Comrission

Washington, DC 20555

G. L. Sjoblom

Environmental Protection Agency

Office of Radiation Programs

401 M Street, S.W.

Washington, DC 20460

J. M. McGough

DOE Albuquerque Operations Office

$P .0$. Box 5400

Albuquerque, NM 87185

P. G. Hagen

Joint Integration office

B1dg. 3, 2nd Floor

2201 San Pedro N.E.

Alhuquerque, NM 87110

E. Maestas

DOE West Valley Operations Office

P.0. Box 191

West Valley, NY 14171

2 DOE Idaho Operations Office

550 Second Street

Idaho Falls, ID 83401

ATTN: M. J. Barainca

J. P. Hamric

F. T. Fong

DOE San Francisco Operations 1333 Broadway

Dakland, CA 94612 
No. of

Copies

M. R. Jugan

DOE Oak Ridge Operations Office P. 0. Box E

Oak Ridge, TN 37830

W. J. Brumley

DOE Savannah River Operations office

P.0. Box A

Aiken, SC 29801

M. 3. Steindler

Argonne National Laboratory

9700 South Cass Avenue

Argonne, IL 60439

C. S. Abrams

Argonne National Laboratory

P.0. Box 2528

Idaho Falls, ID 83401

B. D. Shipp

Battelle Memorial Institute

office of Crystalline

Repository Development

9800 South Cass Avenue

Argonne, IL 60439

3 Battelle Memorial Institute

Project Management Division

$505 \mathrm{King}$ Avenue

Columbus, $\mathrm{OH} 43201$

ATTN: W. A. Carbeiner

W. S. Madia

B. Rawles

F. Holzer

Lawrence Livermore Nationa?

Laboratory

University of California

P. 0. Box 808

Livermore, CA 94550

D. T. Oakley, MS 671

Los Alamos Scientific Laboratory

P.0. Box 1663

Los Alamos, NM 87544
No. of

Copies

4 Oak Ridge Nationa? Laboratory

P.0. Box Y

Oak Ridge, TN 37830

ATTN: J. 0. Blomeke

W. D. Burch

R. T. Jubin

L. J. Mezga

Sandia Laboratories

P.0. Box 5800

Albuquerque, NM 87185

ATTN: Technical Library

J. R. Berreth

Westinghouse Idaho Nuclear Co., Inc.

P. O. Box 4000

Idaho Falls, ID 83401

7 E. I. du Pont de Nemours Company

Savannah River Laboratory

Aiken, SC 29801

ATTN: M. D. Boersma

J. G. Glas scock

F. M. Heckendorn

E. J. Hennelly

J. R. Knight

M. J. Plodinec

C. T. Randall

E. A. Jennrich

EG\&G Idaho

P.0. Box 1625

Idaho Falls, ID 83415

R. Williams

Electric Power Research

Inst itute

3412 Hiliview Avenue

P.0. Box 10412

Palo A1to, CA 94304

5 West Valley Nuclear Services

Company

P.0. Box 191

West Valley, NY 14171

ATTN: S. M. Barnes 
No. of

Copies

West Valley Nuclear Services

Company (contd)

ATTN: C. C. Chapman

J. E. Krauss

S. J. Marchette

J. M. Pope

J. L. Larocca, Chairman

Energy Research \& Development Authority

Empire State Plaza

Albany, NY 12223

ONSITE

4 DOE Richland Operations Office

E. A. Bracken

C. Collantes

M. W. Shupe

J. J. Sutey

J. D. White

11 Rockwell Hanford Operations

R. N. Gurley

J. M. Henderson

H. E. MeGuire

R. D. Prosser

I. E. Reep

J. L. Scott

R. J. Thompson

D. A. Turner

D. D. Wodrich

R. D. Wojtasek

File Copy

UNC United Nuclear Industries

T. E. Dabrowski/W. J. Kyriazia

2 Westinghouse Hanford Company

R. E. Lerch

J. D. Watrous
No. of

Copies

56 Pacific Northwest Laboratory

C. R. Allen

G. A. Anderson

W. W. Ballard, Jr.

W. F. Bonner

R. A. Brouns (2)

J. L. Buelt

H. C. Burkholder

J. R. Carrel1

D. G. Coles

R. D. Dierks

S. K. Ennor

L. J. Ethridge

F. A. Graf

M. S. Hanson

L. K. Holton

Y. B. Katayama

S. S. Koegler

W. L. Kuhn

L. T. Lakey (2)

D. E. Larson

J. M. Latkovich

J. L. McElroy

J. E. Minor

R. K. Nakaoka

K. H. Ona

J. M. Perez, Jr.

M. E. Peterson

A. M. Platt

J. A. Powell

W. A. Ross

K. J. Schneider

K. L. Schuchardt

P. A. Scott

G. J. Sevigny

D. H. Siemens

J. L. Straalsund

N. M. Thomas

J. H. Westsik, Jr. (10)

Publishing Coordination (2)

Technical Information (5) 
